\title{
Implementasi Model Osborn Berbasis IT Pada Matakuliah Kalkulus di Universitas Madura
}

\author{
${ }^{1}$ Chairul Fajar Tafrilyanto, ${ }^{2}$ Harfin Lanya \\ Universitas Madura, Madura, Indonesia
}

Email: 1'chairul_math@unira.ac.id, ${ }^{2}$ lanya_math@unira.ac.id

\begin{tabular}{l}
$\overline{\text { Tersedia Online di }}$ \\
\hline http://www.jurnal.unublitar.ac.id/i \\
ndex.php/briliant
\end{tabular}

Sejarah Artikel

Diterima pada 15 November 2020

Disetujui pada 22 Februari 2021

Dipublikasikan pada 28 Februari 2021

Hal. 87-98

\begin{tabular}{l}
\hline Kata Kunci: \\
\hline Model Osborn; Pembelajaran IT; \\
Kalkulus \\
\hline
\end{tabular}

DOI:

http://dx.doi.org/10.28926/briliant. v3i4.587

\begin{abstract}
Abstrak: Nilai mahasiswa yang rendah pada mata kuliah kalkulus disebabkan karena adanya banyak rumus sehingga mahasiswa keliru dalam memahami konsep. Mahasiswa hanya menghitung tanpa mengetahui konsep yang diterapkan. Oleh sebab itu, diperlukan sebuah model pembelajaran yang membuat mahasiswa mengurangi kesulitan tersebut. Tujuan penelitian ini untuk mengetahui aktivitas, respon dan hasil belajar mahasiswa selama mengimplementasikan model Osborn berbasis IT. Melalui Penelitian Tindakan Kelas diperoleh aktivitas, respon dan hasil belajar mahasiswa berturut-turut mengalami peningkatan sebesar $0,775,17,87 \%$, dan 46,42\%. Peningkatan tersebut dari refleksi yang terus dilakukan dari setiap pembelajaran dengan lebih peka terhadap karakteristik mahasiswa dan memotivasi mahasiswa agar berani berpendapat.
\end{abstract}

\section{PENDAHULUAN}

Kalkulus merupakan salah satu mata kuliah dasar yang harus ditempuh mahasiswa prodi pendidikan matematika Universitas Madura di tahun pertama perkuliahan. Mahasiswa diharapkan bisa menguasai matakuliah kalkulus kerena matakuliah tersebut merupakan dasar dan prasyarat untuk matakuliah selanjutnya. Berdasarkan wawancara yang dilakukan peneliti selaku dosen pengajar matakuliah kalkulus, hampir 50\% dari jumlah mahasiswa yang masuk ke prodi pendidikan matematika bukan karena kemampuan yang dimiliki dalam pelajaran matematika dan keinginan mereka. Ada beberapa diantaranya hanya dipengaruhi oleh faktor teman dan keluarga. Beberapa mahasiswa menganggap mata kuliah kalkulus merupakan matakuliah yang sulit dengan rumus-rumus yang banyak dan rumit. Ketika anggapan seperti ini dibiarkan dapat menyebabkan rasa percaya diri dan pemahaman mahasiswa pada mata kuliah kalkulus akan semakin menurun. Berdasarkan nilai yang diperoleh nilai A (1 orang), AB (1 orang), B (5 orang), BC (3 orang), C (9 orang) dan D (4 orang) yang menunjukkan nilai yang didapatkan tidak sesuai dengan harapan. Hal tersebut dikarenakan kurangnya pemahaman mahasiswa terhadap mata kuliah kalkulus lanjut. Beberapa mahasiswa berpendapat matakuliah kalkulus lanjut memiliki banyak rumus dan dalam penerapannya memerlukan pemahaman tinggi yang melibatkan banyak konsep, sehingga terjadi 
kesalahan untuk memahami konsep dan banyak juga mahasiswa tidak mengetahui sebetulnya apa yang mereka hitung. Untuk mengatasi masalah pembelajaran seperti yang diungkapkan di atas yang terpenting adalah menciptakan suasana perkuliahan yang bermakna. Dosen harus mampu memadukan model pembelajaran yang dapat menarik dan disukai oleh mahasiswa sehingga mahasiswa tidak merasa tertekan, dapat mengemukakan solusi masalah dengan bebas, berkreasi untuk mengembangkan solusi dengan curah pendapat. Salah satu model pembelajaran yang memperhatikan keadaan tersebut ketika proses perkuliahan berlangsung adalah model pembelajaran Osborn, yaitu suatu model pembelajaran dengan menggunakan metode atau teknik brainstorming yang efektif dengan katagori sangat baik (Lanya, 2019) Agar lebih bermakna dalam mengajarkan suatu konsep pada matakuliah kalkulus lanjut yang salah satunya pada materi integral lipat. Untuk membantu mahasiswa agar tetap belajar kalkulus lanjut diperlukan bantuan soal menggunakan IT dari daring berupa whatsApp group dan google form, Sehingga mahasiswa tetap bisa belajar matakuliah kalkulus lanjut dari rumah masing-masing tanpa harus ke kampus.

Penelitian ini bertujuan untuk mengetahui aktivitas belajar, respon dan hasil belajar mahasiswa selama mengimplementasikan model Osborn berbasis IT pada mata kuliah kalkulus lanjut di Universitas Madura. Sehingga mahasiswa akan memperoleh pengetahuan baru tentang Model Osborn berbasis IT dan hasil penelitian ini akan menjadi tambahan referensi khususnya mengenai peningkatan hasil belajar mahasiswa selama mengimplementasikan Model Osborn berbasis IT pada mata kuliah kalkulus lanjut di Universitas Madura

\section{METODE}

\section{Jenis Penelitian}

Penelitian ini merupakan penelitian tindakan kelas (PTK). Penelitian tindakan kelas (PTK) ini bertujuan untuk memperbaiki dan meningkatkan mutu atau kualitas proses pembelajaran di kelas diantaranya. Tindakan yang dilakukan oleh peneliti bertujuan untuk mengatasi permasalahan yang dirumuskan dalam bentuk siklus-siklus yang direncanakan. Dalam setiap siklus mencakup tahap perencanaan (planning), tindakan (action), observasi (observing), dan refleksi (reflecting).

\section{Lokasi dan Subjek Penelitian}

Penelitian ini dilaksanakan di FKIP Universitas Madura Program Studi pendidikan matematika. Subjek dalam penelitian ini adalah mahasiswa semester II sebanyak 28 mahasiswa yang sedang menempuh mata kuliah kalkulus lanjut tahun akademik 2019/2020

\section{Teknik dan Instrumen Pengumpulan Data}

Teknik pengumpulan data dalam penelitian ini mengunakan : 1) observasi pada saat proses pembelajaran berlangsung melalui, dimana kegiatan yang diamati meliputi aktivitas selama proses pembelajaran menggunakan model osborn berbasis IT melalui WhatsApp Grup (kecil dan besar), 2) Pemberian angket respon minat mahasiswa, Angket tersebut diberikan setelah pembelajaran menggunakan model osborn berbasis IT setelah dua kali pertemuan untuk mengetahui minat mahasiswa terhadap pembelajaran menggunakan model osborn berbasis IT. 3) Tes diberikan setelah dua kali pertemuan dengan pembelajaran menggunakan model osborn 
berbasis IT. Instrumen yang digunakan untuk pengumpulan data dalam penelitian ini antara lain : lembar observasi aktivitas mahasiswa yang digunakan observer dalam melihat aktivitas mahasiswa dalam pembelajaran model osborn berbasis IT di WhatsApp Grup , angket respon mahasiswa yang diberikan untuk mengetahui minat mahasiswa dalam bentuk Google Form dan tes hasil belajar yang digunakan untuk mengetahui hasil setelah pembelajaran menggunakan model osborn berbasis IT yang diberikan dalam bentuk Google Form.

\section{Prosedur Penelitian}

Secara umum langkah kegiatan pelaksanaan penelitian ini adalah sebagai berikut: 1)Perencanaan, pada tahap ini, rencana yang akan dibuat adalah sebagai berikut: a) Merumuskan masalah-masalah yang ada di lapangan, b) Menentukan penggunaan materi yang akan disampaikan melalui model Osborn berbasis IT. c) Menyiapkan WhatsApp Grup (kecil dan besar) dan lembar observasi, d) Menyiapkan lembar kuesioner respon mahasiswa dan soal tes dalam bentuk Google Form. 2) Tindakan, melaksanakan pembelajaran menggunakan model Osborn berbasis IT dengan memanfaat WhatsApp Group untuk meningkatkan hasil belajar mahasiswa dalam matakuliah kalkulus lanjut. 3) Observasi, observasi dilakukan oleh peneliti selama pelaksanaan pembelajaran. Pengamatan ini untuk mengidentifikasi hal-hal positif dan kendala-kendala dalam proses pembelajaran baik yang dihadapi mahasiswa maupun dosen selama tindakan pembelajaran dan 4) Refleksi, refleksi dilakukan untuk menganalisis hasil tindakan. Tindakan ini diakhiri dengan indikator sebagai berikut: a) Hasil observasi telah menunjukkan bahwa pelaksanaan pembelajaran menggunakan model Osborn berbasis IT sesuai dengan rencana, b) Hasil respon/angket telah memberikan informasi bahwa mahasiswa telah dapat menilai efek penggunaan model Osborn berbasis IT pada materi integral dan c) Hasil tes telah menunjukkan bahwa mahasiswa menunjukkan peningkatan sesuai ketuntasan belajar klasikal mendapat nilai di atas B yaitu $85 \%$ dari jumlah mahasiswa.

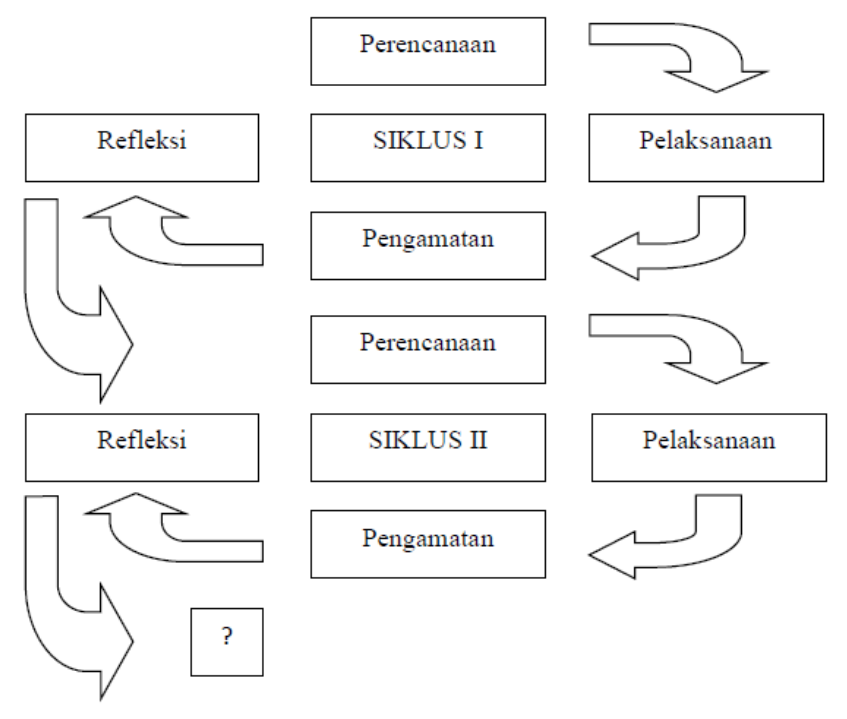

Gambar 1. Alur Siklus Penelitian Tindakan Kelas (Sumber: Suyadi, 2010:50) 


\section{Teknik Analisis Data}

Analisis dilakukan secara kualitatif deskriptif berdasarkan observasi terhadap proses proses pembelajaran, respon mahasiswa, dan hasil belajar dengan langkah berikut: 1) Melakukan pengelolaan data, yaitu mengecek, mencatat, dan memastikan validitas data- data yang telah terkumpul, 2) Melakukan interpretasi, yaitu menafsirkan data dengan mengacu pada masalah penelitian, 3) Melakukan inferensi, yaitu menyimpulkan apakah setelah dilakukan tindakan, terjadi peningkatan hasil belajar mahasiswa selama proses penggunaan model Osborn berbasis IT dan 4) Pengambilan kesimpulan dan penentuan implikasi teoritis dan/atau praktis dari penelitian.

\section{HASIL}

\section{Siklus 1}

Pada siklus 1 terdiri dari dua kali pertemuan. Dalam hal ini peneliti menentukan pertemuan ke 11 dan ke 12 sebagai siklus 1 . Dengan tahapan sebagai berikut :

\section{Pertemuan ke 11}

1) Tahap Perencanaan, Tahap perencanaan dalam PTK merupakan komponen yang paling penting dan langkah awal yang harus dipersiapkan dengan baik oleh peneliti. Perencanaan yang dilakukan antara lain : a) Perangkat pembelajaran, Perangkat pembelajaran yang dibuat meliputi Rencana Pembelajaran Mingguan (RPM) yang terdiri dari RPM 1 (pertemuan ke-11) dengan materi integral lipat dua pada persegipanjang dan RPM 2 (pertemuan ke-12) dengan materi integral berulang. Lembar Kerja Mahasiswa (LKM) yang terdiri dari dua LKM yaitu LKM 1 dan LKM 2 dengan materi sesuai dengan RPM yang sudah dibuat dan Tes hasil belajar dengan menggunakan Google Form yang berisi soal dengan materi yang sesuai dengan LKM 1 dan LKM 2. Peneliti juga menyusun instrumen penelitian lembar observasi aktivitas mahasiswa serta angket respon mahasiswa terkait terkait pembelajaran yang di implementasikan. Setelah peneliti membuat semua perangkat dan instrumen penelitian,dilanjutkan dengan proses validasi kepada 2 validator untuk mengecek kevalidan data atau kelayakan perangkat pembelajaran dan instrumen layak digunakan atau tidak. Dalam pembelajaran menggunakan model osborn berbasis IT, mengorganisasikan mahasiswa menjadi beberapa kelompok, dimana masing-masing kelompok terdiri dari 4 mahasiswa dengan kemampuan heterogen berdasarkan hasil penilaian pada mata kuliah sebelumnya c) Penetapan Pengamat (Observer), Dalam penelitian ini menggunakan 2 orang observer untuk mengamati aktivitas mahasiswa selama penelitian.

2) Tahap Tindakan a) Pendahuluan, Pembelajaran pada pertama siklus 1 dilaksanakan pada tanggal 8 Juni 2020. Dosen melaksanakan pembelajaran sesuai dengan RPM yang telah dibuat. Dosen membuat kelas melalui media WhatsApp Group yaitu "Kelas Kalkulus Lajut" yang beranggotakan mahasiswa semester 2 yang sedang menempuh matakuliah kalkulus lanjut, Dosen mengucapkan salam dan melakukan presensi melalui pengisian google form oleh mahasiswa, Dosen melakukan tanya jawab pada mahasiswa yang berkaitan dengan integral lipat dua pada persegi panjang, yaitu dengan metode apa saja yang bisa digunakan untuk menyelesaikan masalah itu melalui media WhatsApp Group, Dosen memberikan kesempatan kepada mahasiswa untuk memikirkan jawabannya, Dosen meminta 
beberapa mahasiswa untuk mengemukakan pendapatnya dalam forum diskusi WhatsApp Group. Setelah itu melaksanakan tahap pertama Penemuan Tujuan Pembelajaran yaitu : mengemukakan tujuan pembelajaran yang akan dibahas dalam WhatsApp Group adalah menentukan nilai integral lipat dua pada persegi panjang, Dosen mengorgaisasikan mahasiswa dalam 7 kelompok yang heterogen dengan setiap kelompok beranggotakan 4 orang dan menginstruksikan kepada mereka untuk membuat kelompok kecil (WhatsApp Group), Mahasiswa membuat kelompok kecil (WhatsApp Group) sesuai dengan instruksi dosen yang di dalamnya beranggotakan 4 orang mahasiswa, dosen dan observer dan Dosen memberikan LKM 1 kepada mahasiswa melalui WhatsApp Group dan meminta mahasiswa untuk memahami petunjuk kerjanya b) Kegiatan Inti, Tahap kedua Penemuan Fakta yaitu : Masing-masing mahasiswa diminta membaca dan memahami masalah yang ada di LKM 1, Setelah mahasiswa memahami masalah, mahasiswa diminta untuk menuliskan fakta-fakta yang ada dan apa yang ditanyakan pada masalah 1, 2 dan 3 kemudian melanjutkan ke proses penyelesaian masalah tersebut, Mahasiswa diminta bertanya dalam forum diskusi kelas melalui WhatsApp Group jika menemukan fakta-fakta yang belum dipahami . Tahap ketiga Pemecahan Masalah yaitu : Mahasiswa memecahkan masalah secara individu berdasarkan fakta-fakta yang ditemukan (informasi yang diketahui dan yang ditanyakan pada masalah) Mahasiswa bertanya dalam forum diskusi kelas melalui WhatsApp Group jika mengalami kesulitan dalam memecahkan masalah Mahasiswa diminta menuliskan hasil pemikirannya (gagasan) pada LKM 1, setelah menemukan solusi dari masalah dan berdasarkan data-data yang ditemukan sebelumnya. Tahap keempat Penemuan Gagasan yaitu : Setelah jawaban masingmasing individu mahasiswa dituliskan pada LKM 1, mahasiswa diminta menyimpulkan hasil kerjanya sesuai gagasan yang dipikirkan dan dipahami dari penyelesaian semua masalah melalui forum diskusi kelompok kecil (WhatsApp Group). Mahasiswa diminta mengemukakan gagasan sebanyak mungkin dalam forum diskusi kelompok kecil (WhatsApp Group) terkait soal yang telah diidentifikasi sebelumnya. Mahasiswa yang pasif diberi motivasi oleh dosen untuk aktif dalam diskusi kelompok kecil, baik itu WhatsApp Group kelompok kecil dan WhatsApp Group kelas (besar). Tahap kelima Penemuan Solusi yaitu : Setelah menuliskan gagasan secara individu, melakukan diskusi kelompok untuk menyatukan dan menyamakan persepsi dalam kelompok kecil (WhatsApp Group), mahasiswa menyimpulkan jawaban yang terbaik atas masalah yang ada pada LKM 1, Mahasiswa menuliskan kesimpulan hasil diskusi kelompok kecil (WhatsApp Group) di LKM dan Dosen memotivasi mahasiswa yang pasif di dalam kelompoknya. Tahap keenam Penerimaan yaitu : Meminta mahasiswa menyiapkan jawaban kelompok untuk dipresentasikan dalam forum diskusi kelas WhatsApp Group, Meminta masing-masing kelompok secara bergantian untuk mempresentasikan hasil diskusi dalam forum diskusi kelas WhatsApp Group dengan cara mengirimkan jawaban dalam bentuk JPG/PDF kemudian perwakilan dari kelompok tersebut menjelaskan jawabannya menggunakan Voicenote, Memberikan kesempatan kepada masing-masing mahasiswa atau kelompok untuk bertanya dan memberikan tanggapan terhadap hasil presentasi kelompok lain, Mengecek kebenaran jawaban mahasiswa dan menyimpulkannya dan Mahasiswa 
bersama dosen menyimpulkan manakah jawab paling benar/solusi terbaik. c) Penutup, Pada tahap ini Dosen merefleksi dan menyimpulkan hasil pembelajaran dengan bertanya kepada mahasiswa tentang langkah-langkah menentukan Integral lipat dua pada persegi panjang dalam forum diskusi kelas WhatsApp Group, Dosen mengingatkan mahasiswa untuk mempelajari materi selanjutnya yaitu integral berulang dan Dosen menutup pembelajaran dengan mengucapkan salam penutup.

\section{Pertemuan ke-12}

Tahapan yang dilakukan pada pertemuan 12 ini sama seperti pada pertemuan 11 hanya saja perbedaannya adalah mahasiswa diberikan LKM 2. Pada pertemuan ke-12 ini sudah menunjukkan beberapa perbaikan dari temuan pada pertemuan ke-11. Kelemahan-kelemahan yang menyebabkan permasalaha yang terjadi di pertemuan ke-11 diantisipasi oleh peneliti dan observer sehingga pembelajaran bisa lebih baik.Upaya yang dilakukan antara lain memotivasi mahasiswa agar terus semangat walaupun belajar melalui media online,lebih menjelaskan lagi langkah-langkah model pembelajaran Osborn, berusaha mengarahkan mahasiswa untuk mengigat apersepsi dari materi yang akan dipelajari, memotivasi mahasis yang masih kurang aktif dengan memberikan semangat untuk bisa lebih aktif lagi, meminta mahasiswa untuk merespon instruksi dosen, mengingatkan mahasiswa untuk mencari posisi jaringan yang baik agar bisa mengikuti jalannya pembelajaran dengan maksimal, memotivasi mahasiswa agar selalu aktif dalam kelompok kecil dengan cara berkomentar dalam kelompok kecil sehingga mahasiswa merasa diperhatikan dalam kelompok kecil. Membatasi soalsoal yang ada di LKM untuk dipresentasikan secara bergantian dari masing-masing kelompok. Memotivasi mahasiswa untuk tidak takut salah dalam berpendapat dan menekannya berpendapat salah lebih baik daripada yang tidak berpendapat dan selalu membimbing mahasiswa untuk membuat kesimpulan.

Selain itu, berdasarkan angket yang diberikan pada siklus 1 sebanyak $70,25 \%$ yang merespon positif terhadap penggunaan model pembelajaran Osborn berbasis IT. Hal tersebut selaras dengan hasil tes yang sudah diberikan pada siklus 1. Rata-rata tes hasil belajar mencapai 70,11 sedangkan dari 28 mahasiswa hanya 12 mahasiswa yang tuntas dengan persentase $42,86 \%$ dan secara klasikal kurang dari $85 \%$. Berdasarkan hal tersebut dapat ditarik kesimpulan bahwa siklus 1 belum berhasil dan harus dilakukan tindakan kembali berupa siklus 2 .

Setelah selesai siklus 1 dan melihat hasil tes. Peneliti dan observer berdiskusi, observer menyarankan masalah dalam LKM tidak terlalu banyak cukup 1 soal dalam setiap masalah. Akan tetapi soal yang diberikan mencakup keseluruhan materi yang akan dibahas sehingga nantinya pada waktu presentasi tidak terlalu membutuhkan banyak waktu. Dosen perlu meningkatkan motivasinya pada mahasiswa agar mahasiswa terus bersemangat dalam mengikuti pembelajaran. Saran-saran tersebut harus diperbaikan pada pembelajaran di siklus 2 .

\section{Siklus 2}

Pada siklus 2 terdiri dari dua kali pertemuan. Dalam hal ini peneliti menentukan pertemuan ke 13 dan ke 14 sebagai siklus 2. Dengan tahapan sebagai berikut :1) Tahap Perencanaan, Setelah melakukan refleksi pada siklus 1 maka peneliti meyusun rencana untuk memperbaiki atau meminimalisir kekurangan yang ada. Yang paling penting dalam siklus 2 ini peneliti menjelaskan lebih detail 
langkah-langkah penggunaan model pembelajaran Osborn dan mengurangi jumlah soal dalam masalah 1, 2 dan 3 pada LKM serta membahas soalyang akan diprsentasikan mencakup keseluruhan materi yang dipelajari.Dosen juga meningkatkan motivasi agar siswa bisa aktif dalam kelompok kecil untuk berdiskusi. Selanjutnya peneliti mempersiapkan hal-hal pada tahap pelaskanaan diantaranya: a) Perangkat pembelajaran, Perangkat pembelajaran yang dibuat meliputi Rencana Pembelajaran Mingguan (RPM)) dengan materi integral lipat dua pada daerah bukan persegipanjang dan RPM 4 (pertemuan ke-14) dengan materi integral lipat tiga dalam koordinat cartesius. Lembar Kerja Mahasiswa (LKM) yang terdiri dari dua LKM yaitu LKM 3 dan LKM 4 dengan materi sesuai dengan RPM yang sudah dibuat dan Tes hasil belajar dengan menggunakan Google Form yang berisi soal dengan materi yang sesuai dengan LKM 3 dan LKM 4 yang telah dipelajari. Peneliti juga menyusun instrumen kemudian divalidasi kepada 2 validator untuk mengecek kevalidan data atau kelayakan perangkat pembelajaran dan instrumen layak digunakan atau tidak. b) Pembagian Kelompok, Dalam pembelajaran menggunakan model osborn berbasis IT, masih tetap sama dengan kelompok sebelumnya.c) Penetapan Pengamat (Observer), Dalam penelitian siklus 2 masih tetap menggunakan 2 orang observer untuk mengamati aktivitas mahasiswa selama penelitian.

2) Tahap Tindakan Pertemuan 13 a) Pendahuluan, Pembelajaran pada pertemuan pertama siklus 2 dilaksanakan pada tanggal 15 Juni 2020. Dosen melaksanakan pembelajaran pada materi integral lipat dua pada daerah bukan persegi panjang, dengan langkah-langkah kegiatan sama dengan siklus satu akan tetapi terdapat perbaikan sesuai refleksi dari siklus 1. c) Penutup, Pada tahap ini Dosen merefleksi dan menyimpulkan hasil pembelajaran dengan bertanya kepada mahasiswa tentang langkah-langkah menentukan Integral lipat dua pada daerah bukan persegi panjang dalam forum diskusi kelas WhatsApp Group, Dosen mengingatkan mahasiswa untuk mempelajari materi selanjutnya yaitu integral lipat tiga dalam koordinat cartesius.

\section{Pertemuan 14}

Tahapan dalam pertemuan ini sama seperti pertemuan sebelumnya hanya saja pada tahap ini, mahasiswa diberikan LKM 4. Hal-Hal yang ditemukan peneliti dan observer pada pelaksanaan siklus 2 pada pertemuan 14 sebagai berikut : Pada pertemuan ke-14 ini sudah menunjukkan peningkatan dari temuan pada pertemuan ke-13. Kelemahan-kelemahan yang menyebabkan permasalahan yang terjadi di pertemuan ke12 diperbaiki oleh peneliti dan observer sehingga pembelajaran bisa lebih baik. apa yang diharapkan peneliti sudah tercapai semua kelemahan dan kekurangan sudah teratasi. Selain itu, berdasarkan angket yang diberikan pada siklus 2 sebanyak 88,12\% yang merespon positif terhadap penggunaan model pembelajaran Osborn berbasis IT. Hal tersebut selaras dengan hasil tes yang sudah diberikan pada siklus 2. Rata-Rata tes hasil belajar mahasiswa mencapai 86,75 sedangkan 28 mahasiswa terdapat 25 mahasiswa yang tuntas denganpersentase $88,12 \%$ dan secara klasikal lebih dari $85 \%$. Berdasarkan hal tersebut dapat ditarik kesimpulan bahwa siklus 2 sudah berhasil maka tidak perlu dilakukan siklus berikutnya. Berikut disajikan hasil observasi aktivitas siswa, angket respon siswa dan tes mahasiswa dari siklus 1 ke siklus 2 . 


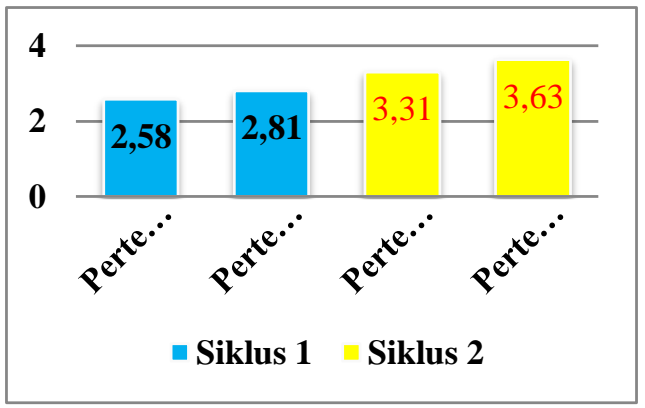

Gambar 2. Hasil Observasi Mahasiswa

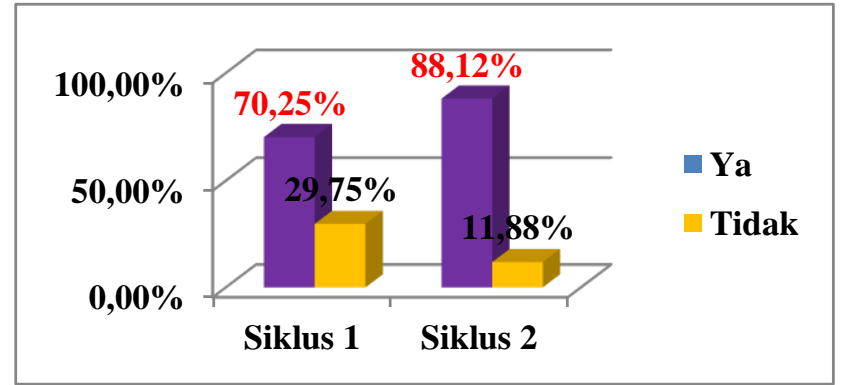

Gambar 3. Hasil Respon Mahasiswa

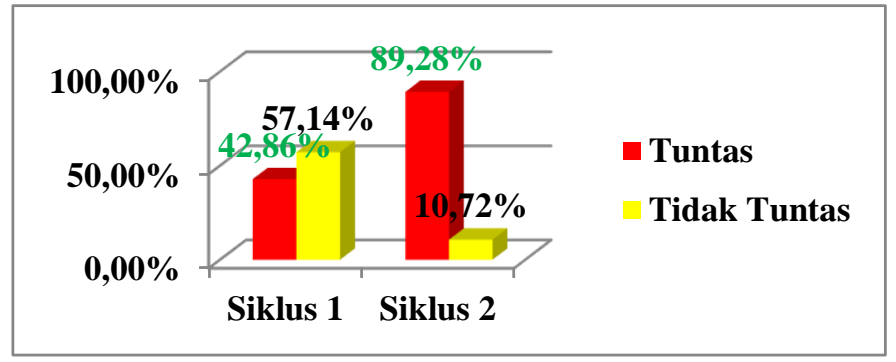

Gambar 4. Tes Hasil Belajar Mahasiswa

\section{PEMBAHASAN}

Peneliti merupakan pengampu mata kuliah kalkulus lanjut di prodi pendidikan matematika Universitas Madura. Peneliti merasa perlu adanya variasi model pembelajaran agar mahasiswa tidak bosan menggunakan pembelajaran secara konvensional atau pembelajaran langsung. Dengan memadukan model pembelajaran baru yaitu model pembelajaran osborn yang tidak biasa bagi mahasiswa, kemudian model pembelajaran tersebut dipadukan dengan media berbasis IT salah satunya WhatsApp Group untuk berdiskusi dan Google Form sebagai sarana untuk mengisi absensi dan menjawab soal tes yang tidak biasa digunakan mahasiswa. Karena sehari-harinya ketika mahasiswa mengikuti perkuliahan menggunakan absensi secara manual dan soal tes pun dikerjakan secara manual. Alasan pemilihan Osborn tersebut karena Model pembelajaran osborn merupakan model pembelajaran yang efektif karena lebih bermakna mengajarkan suatu konsep mata kuliah (Lanya, 2019). Model pembelajaran Osborn tersebut akan dipadukan dengan pembelajaran daring berbasis IT dengan WhatsApp Group untuk mendiskusikan materi-materi pada LKM 1 sampai dengan LKM 4 sedangkan Google Form digunakan untuk mengisi absensi selama 4 kali pertemuan dan mengerjakan soal Tes 1 dan Tes 2 . Hasil pre test yang dilakukan peneliti sebelum 
awal pertemuan menunjukan hasil yang sangat minim,karena ketuntasan yang diperoleh hanya $28,57 \%$. Berdasarkan hasil tersebut perlu dilakukan tindakan agar hasil belajar mahasiswa bisa lebih baik.

Hasil penelitian menunjukkan bahwa ada peningkatan yang signifikan terkait hasil belajar mahasiswa pada matakuliah kalkulus lanjut dengan mengimplementasikan model pembelajaran Osborn berbasis IT dari siklus 1 ke siklus 2. Pada siklus 1 pertemuan ke 11 mahasiswa masih belum terbiasa menggunakan model pembelajaran Osborn. Hal ini ditunjukkan mahasiswa masih banyak yang dengan langkah-lagkah pada pembelajaran Osborn terutama dalam membuat gagasan berdasarkan fakta yang sudah didapatkan. Hal tersebut menghambat proses pembelajaran pada pertemuan ke 11,sehingga pertemuan ke 11 harus selesai melebihi waktu yang telah ditentukan. Banyak sekali permasalahan yang ditemukan di pertemuan 11 terkait dengan mahasiswa yang mungkin mulai bosan dengan pembelajaran online karena tidak bisa bertatap muka langsung sehingga kurang sempurna dalam proses pembelajaran.

Akan tetapi hal tersebut memang harus dilakukan sesuai dengan kebijakan kampus terkait masa pandemi, dimana pembelajaran yang harus dilakukan secara daring. Kesulitan juga dirasakan mahasiswa terkait langkah-lagkah model pembelajaran Osborn karena mahasiswa belum pernah belajar menggunakan langkah-langkah tersebut. Mahasiswa juga mengalami kesulitan dalam megungkapkan materi apersepsi terkait dengan materi integral lipat pada persegipanjang yaitu integral tentu yang sudah pernah mereka pelajari sebelumnya. Pada pertemuan ke 11 tersebut dosen menekankan mahasiswa untuk selalu aktif dalam berdiskusi baik di group besar (group kelas) ataupun group diskusi pada kelompok kecil. Dosen selalu memantau aktivitas mahasiswa dalam berdiskusi kelompok. dosen selalu memotivasi mahasiswa yang dipantau pasif dengan cara menegur untukmemberi semangat agar terus berdiskusi.Pada pertemuan ke11 juga terdapat masalah pada jaringan mahasiswa karena bisa juga sinyal dimana siswaberada tidak kuat,sehingga pebelajaran tidak maksimal. Hal tersebut menyebabkan mahasiswa terlalu lama dalam merespon instruksi dari dosen.

Berdasarkan komentar dari observer soalyang diberikan pada mahasiswa dalam LKM terlalu banyak sehingga mahasiswa membutuhkan banyakwaktu untukmempresentasikan hasil pekerjaan terbaiknya berdasarkan hasil diskusi kelompok. pada pertemuan ke 11 dosen juga selalu memotivasi mahasiswa agar tidak merasa takut dalam berpendapat menggunakan voicenote. Sehingga mahasiswa lebih percaya diri dalam mempresentasikan atau mengungkapkan permasalahan yang dirasakan pada waktu pembelajaran berlangsung.

Berdasarkan hasil observasi pada siklus 1 dari pertemuan ke 11 dan 12 menujukkan adanya peningkatan rata-rata aktivitas belajar mahasiswa walaupun masih belum terlalusignifikan yaitu dari 2,58 menjadi 2,81 sehingga walaupuan rata-ratanya meningkat dapat disimpulkan bahwa peningkatanya masih kurang signifikan. Akan tetapi respon mahasiswa terkait penggunaan model pembelajaran Osborn positif mencapai 70,25\%. Mahasiswa memiliki pemahaman yang baru tetang suatu model pembelajaran yang membuat mahasiswa merasa terbantu dengan cara melakukan diskusi kelompok. Tes hasil belajar mahasiswa masih belum bisa dikatakan berhasil karena ketuntasan tes hasil belajar mahasiswa masih 
mencapai 57,14\% karena 16 mahasiswa dinyatakan tuntas sehingga masih kurang dari $85 \%$ ketuntasan secara klasikal. Hal ini seiring dengan aktivitas hasil belajar dan respon mahasiswa yang tidak terlalu signifikan. Kesulitan yang dialami mahasiswa terkait soal nomor 5 yang pada tes. Dimana siswa tidak bisa menggambar hasil bangun benda pejal. Sehingga dosen perlu membimbing mahasiswa kembali agar terkait aplikasi yang berupa benda pejal pada integral lipat. Sehingga berdasarkan kekurangan yang masih belum tercapai pada siklus 1,maka perlu dilakukan siklus 2 untuk perbaikan dari siklus 1 .

Berdasarkan hasil observasi pada siklus 2 dari pertemuan ke 13 dan 14 menunjukkan adanya peningkatan rata-rata aktivitas belajar mahasiswa walaupun masih belum terlalusignifikan yaitu dari 3,31 menjadi 36,3 dengan dengan penigkatan tersebut dapat dikategorikan mengalami peningkatan yang signifikan. Begitu juga dengan respon mahasiswa terkait penggunaan model pembelajaran Osborn positif mencapai $88,12 \%$. Sehingga dapat dikatakan mahasiswa sudah mulai memahami tentang penggunaan model pembelajaran Osborn berbasis IT. Tes hasil belajar mahasiswa sudah bisa dikatakan berhasil karena ketuntasan tes hasil belajar mahasiswa masih mencapai 89,28 \% karena 25 mahasiswa sudah dinyatakan tuntas sehingga lebih dari $85 \%$ ketuntasan secara klasikal. Hal ini sesuai dengan aktivitas hasil belajar dan respon mahasiswa yang mengalami peningkatan signifikan. Sehingga dengan adanya peningkatan tersebut maka tidak perlu dilanjutkan pada siklus berikutnya.

Sehingga dapat diambil kesimpulan berdasarkan siklus 1 dan 2 dapat dikatakan semua aspek terkait aktivitas belajar mahasiswa, respon mahasiswa dan tes hasil belajar mahasiswa Implementasi Model Osborn Berbasis IT Pada Matakuliah Kalkulus di Universitas Madura. Untuk rata-rata aktivitas belajar mahasiswa mengalami peningkatan sebesar 0,775 dari 2,695 pada siklus 1 menjadi 3,47 pada siklus 2 . Untuk rata-rata respon siswa pada mengalami peningkatan sebesar $17,87 \%$ dari $70,25 \%$ pada siklus 1 menjadi $88,12 \%$ pada siklus 2 , sedangkan untuk tes hasil belajar juga mengalami peningkatan rata-rata ketutasan hasibelajar sebesar 46,42\% dari 42,86 pada siklus 1 menjadi 89,28\% pada siklus 2 . Sehingga dapat dikatakan semua aspek mengalami peningkatan. Hal ini sejalan dengan penelitian Widodo (2018) bahwa penggunaan media pembelajaran dapat meningkatkan kemampuan mahasiswa dalam memecahkan masalah dan meningkatkan prestasi belajar.

Berdasarkan hasil dari refleksi yang terus dilakukan untuk memperbaiki hasil dari setiap pembelajaran dan yang paling utama adalah dosen harus lebih peka terhadap karakteristik mahasiswa yang berbeda-beda dan terus memotivasi mahasiswa agar berani dalam mengungkapkan pendapatnya. Hal ini sesuai dengan pendapat Herges (2017) yang menyatakan bahwa pemberian motivasi sangat diperlukan dalam peningkatan hasil belajar. Pemberian motivasi bisa dilakukan dengan selalu menerapkan ungkapan "lebih baik menjawab salah daripada tidak menjawab" dan terus melatih kemampuan komunikasi mahasiswa dalam mengungkapkan dengan voicenote setiap langkah yang mahasiswa tuliskan. sehingga mahasiswa bisa berani mengkomunikasikan jawabannya. 


\section{KESIMPULAN}

Berdasarkan hasil penelitian yang telah dilakukan pada Implementasi Model Osborn Berbasis IT Pada Matakuliah Kalkulus di Universitas Madura. dapat dibuat kesimpulan dari siklus 1 dan 2 dimana semua aspek terkait aktivitas belajar mahasiswa, respon mahasiswa dan tes hasil belajar mahasiswa dengan rata-rata aktivitas belajar mahasiswa mengalami peningkatan sebesar 0,775 dari 2,695 pada siklus 1 menjadi 3,47 pada siklus 2 . Untuk rata-rata respon mahasiswa pada mengalami peningkatan sebesar 17,87\% dari 70,25\% pada siklus 1 menjadi 88,12\% pada siklus 2, sedangkan untuk tes hasil belajar juga mengalami peningkatan ratarata ketutasan hasil belajar sebesar $46,42 \%$ dari 42,86 pada siklus 1 menjadi $89,28 \%$ pada siklus 2 . Semua peningkatan tersebut berdasarkan hasil dari refleksi yang terus dilakukan untuk memperbaiki hasil dari setiap pembelajaran dan yang paling utama adalah dosen harus lebih peka terhadap karakteristik mahasiswa yang berbeda-beda dan terus memotivasi mahasiswa agar berani dalam mengungkapkan pendapatnya dan selalu menerapkan ungkapan "lebih baik menjawab salah daripada tidak menjawab" dan terus melatih kemampuan komunikasi mahasiswa dalam mengungkapkan dengan voicenote setiap langkah yang mahasiswa tuliskan. sehingga mahasiswa bisa berani mengkomunikasikan jawabannya.

\section{SARAN}

Saran yang diberikan peneliti sebagai sumbangan implementasi model osborn berbasis IT pada matakuliah kalkulus di universitas madura yaitu model osborn dapat digunakan sebagai alternatif model pembelajaran pada mata kuliah yang lain, bukan hanya pada mata kuliah kalkulus, Model osborn juga bisa dipadukan dengan pembelajaran daring yang berbeda misalnya dengan Google Meet atau Zoom Meeting. Jika memungkinkan dapat menggunakan aplikasi maple, matlab atau geogebra untuk menyelesaikan permasalahan-permasalahan yang terkait dengan materi kalkulus yang berupa gambar luas suatu bidang atau volume suatu bangun. Karena imajinasi mahasiswa kadang tidak bisa menjangkau aplikasi dari sebuah integral yang berupa gambar apabila tidak digambarkan terlebih dahulu.

\section{DAFTAR RUJUKAN}

Lanya, Harfin, Septi DA., 2019. Efektifitas Model Pembelajaran Osborn Dengan TeknikBrainstorming Pada Mata Kuliah Metode Numerik. Jurnal Indomath (Indonesia mathematic education). Vol 2 No 1. Universitas Sarjanawiyata Tamansiswa. Diakses tanggal 1 Februari 2020.

Sukamti. 2015. Pengembangan Perangkat Pembelajaran Model Osborn dengan Teknik Brainstorming Materi Aritmetika Sosial. Tesis. Universitas Negeri Surabaya

Mustakim. 2020. Efektivitas Pembelajaran Daring Menggunakan Media Online SelamaPandemi COVID-19 Pada Mata Pelajaran Matematika”. Journal Of Islamic Education Vol. 2, No. 1, Mei 2020 diakses tanggal 6 Juni 2020.

Lanya, Harfin, Septi DA., 2018. Pembelajaran Osborn Dengan Teknik Brainstorming Berbantuan Aplikasi Matlab Materi Akar Persamaan Tak Linear. Jurnal Briliant (jurnal riset dan konseptual). Vol 3 No 3. Universitas 
Nahdatul Ulama Blitar diakses tanggal 1 Februari 2020.

Huda, Miftahul. 2014. Model-model Pengajaran dan Pembelajaran. Yogyakarta: Pustaka Pelajar.

Eko kurtanto, Journal Indonesian Language Education and Literature. Keefektifan Model Pembelajaran Daring Dalam Perkuliahan Bahasa Indonesia Di Perguruan Tinggi Vol. 3,No. 1, Desember 2017 halm. 99-110. diakses tanggal 15 Januari 2020

Sudjana, S.Djuju. 2001. Metode dan Teknik Pembelajaran Partisipatif. Bandung.Falah Production.

Suyadi, 2010. Panduan Penelitian Tindakan Kelas. Jogjakarta: Diva Press.

Widodo, S.A. 2018. Selection of Learnin Media Mathematics for Junior School Students. Turkish Online Journal of Educational Technology-TOJET, 17(1), 154-160. diakses tanggal 9 Februari 2020.

Herges, Rebecca M., Duffield, Stacy., Martin, William., and Wageman, Justin.

2017. Motivation and Achievement of Middle School Mathematics Student.

The Mathematics Educator. Vol. 26 No. 1. diakses tanggal 9 Februari 2020. 